\title{
Anti-classicismo, mística judaica, símbolo e alegoria
}

\section{Carla Milani Damião, UFG}

Resumo: Esse artigo corresponde a um recorte do tema sobre o declínio da experiência e da crise da narração. Trata-se de um texto muito próximo ao aprendizado deste assunto desenvolvido em anos de um dedicado trabalho de orientação de Jeanne Marie Gagnebin, do qual resultou uma dissertação de mestrado e uma tese de doutorado. Ressalte-se, na discussão apresentada, o contexto acadêmico-político da oposição entre símbolo e alegoria reunido a uma remissão crítica ao classicismo alemão presentes no Trauerspielbuch e outros textos geralmente associados a este. O tema da mística judaica, o valor religioso do símbolo e o conceito de origem formam o pano de fundo da discussão.

Palavras-chave: símbolo; alegoria; classicismo.

\section{Introdução}

Nenhum outro texto que escrevi possui maior proximidade com o aprendizado que tive de Walter Benjamin sob a supervisão de Jeanne Marie Gagnebin do que este que ora apresento. Descobri, em um arquivo no subsolo da biblioteca da PUC-SP, uma cópia de seu texto intitulado "Alegoria: que outro dizer?". Em aula, surpresa, ela perguntou onde eu havia encontrado este texto. Deveria ter dito: "escavando nas camadas profundas de arquivos mal classificados e desarrumados no subsolo da biblioteca". Desde a leitura desse texto pude observar muitos desdobramentos que resultaram posteriormente em artigos e capítulos de seus livros. Para mim, naquele momento acanhado de um mestrado recém-iniciado em meados de 1990, entender o estilo ensaístico-filológico deste primeiro texto tornou a alegoria uma chave mestra de compreensão da filosofia de Benjamin. Antes de relacioná-la ao tema da modernidade e à poesia de Baudelaire, há o nó a desatar da oposição estabelecida pelo classicismo alemão entre símbolo e alegoria. Este nó se encontra na obra de difícil compreensão que chamaremos, neste artigo, pelo nome em alemão: o Trauerspielbuch ${ }^{1}$, que será, em parte, nosso foco de atenção. Outro autor subjacente ao texto que apresento é Irving Wohlfarth, intérprete de grande importância nos estudos benjaminianos, cuja afinidade com Jeanne Marie, particularmente neste assunto, e no tema do messianismo judaico, foi selada em uma das muitas dedicatórias que costumam abrir os ensaios da autora. $\mathrm{O}$ artigo a ele dedicado "Teologia e messianismo no pensamento de Walter Benjamin", fruto de uma palestra de 1998 apresentada em Turim, repercute o interesse comum pelos temas da teologia judaica que exploraremos também neste artigo.

A terceira fonte importante em nossa discussão é o classicismo ou o anticlassicismo de Benjamin. Ainda no contexto de estudo e recepção do pensamento de Walter Benjamin no Brasil, a publicação Walter Benjamin. Documentos de cultura.

Cadernos Benjaminianos, Número especial, Belo Horizonte, 2013, página 55-69 
Documentos de barbárie: escritos escolhidos forneceu uma ênfase neste assunto. $\mathrm{Na}$ apresentação da coletânea de textos de Benjamin, o organizador ressalta:

República de "Weimar", o nome oficial do Estado alemão a partir de 1919, denota a intenção de restaurar os valores do Classicismo, o legado de Schiller e Goethe, como se tivessem permanecido incólumes. Contra essa atitude Benjamin mobiliza uma outra tradição, recalcada: a do Barroco, em que a violência histórica não era camuflada sob teorias estéticas harmoniosas e, sim, ostentada. ${ }^{2}$

Para Bolle, que oferece a tradução do capítulo central do Trauerspielbuch, "Alegoria e drama barroco", a alegoria é uma "peça-chave de uma história política da escrita". ${ }^{3}$ É o que confirma Burkhardt Lindner, no artigo-verbete "Allegorie", de Benjamins Begriffe:

Benjamin torna inequivocamente claro que este livro tem a intenção de rejeitar uma ideologia do simbólico de sua época. Ele é dirigido contra um direcionamento da Universidade alemã, que alguns anos após serviu, de maneira inalterada e inescrupulosa, a Alemanha nazista. A função política obscura desta metafísica da arte foi prevista por Benjamin na resenha Literaturgeschichte und Literaturwissenschaft, em frases como as que seguem: "Com mais essa força avassaladora e pureza dos valores espirituais surgem ideias. Ideias, que deixam vibrar a alma do poeta e conduzem à irritante forma simbólica" (III, 286). Contra o substituto filosófico-teológico da Germanística, articulada à "O vazio na recente crítica de arte" ["Öde in der neueren Kunstkritik"; I, p. 337], Benjamin insiste criticamente no horizonte do problema do idealismo alemão. "Ainda hoje", ele afirma em sua tese, o "estado da filosofia da arte alemã permanece em torno de 1800 , tal como se apresenta nas teorias de Goethe e na dos primeiros românticos, legítimo" (I, p. 117). Data daquela época, a distinção antagônica entre símbolo (vivo) e alegoria (inartística). Problematizar esta rejeição do alegórico como um sintoma do recalque e incompreensão do barroco é a intenção do livro sobre o Trauerspiel. ${ }^{4}$

Tendo como motivação a leitura desses intérpretes e de outros textos menos referenciados de Benjamin, procurei mostrar de maneira indireta o motivo político subjacente ao tema da alegoria, ao Trauerspielbuch, e o referencial da mística judaica no combate ao classicismo presente no contexto histórico contemporâneo ao filósofo.

Tomemos como exemplo um texto de juventude de Benjamin, de 1916, intitulado "Das Glück des antiken Menschen" ("A sorte dos antigos"). Neste, Benjamin cita Schiller, fala da separação entre homem e natureza, da dor do rompimento, do qual surgem, como "sintomas", a reflexão e o sentimento de nostalgia. O vínculo íntimo que o homem antigo possuía com a natureza em sua grandeza ou com o cosmos reduziu-se, no homem moderno, a uma relação que além de ignorar a natureza, concentrou-se em pequenas coisas, em microcosmos. O destino do homem antigo era ligado aos deuses e sua sorte dependia da crença para alcançar a vitória. O herói da epopeia personificava o destino da humanidade antiga, sorte que se concluía na "festa da vitória", com o recebimento de triunfos e glórias. Já numa outra resenha,

Cadernos Benjaminianos, Número especial, Belo Horizonte, 2013, página 55-69 
de 1931, intitulada "Das Problem des Klassischen und die Antike" ("O problema do clássico e da Antiguidade"), Benjamin considera o conceito de clássico sob as prerrogativas já descritas, ou seja, a constatação da perfeição helênica, cuja completude revelava uma estreita ligação entre homem, natureza e divino, levando em conta também a tese de que, da antiguidade grega aos nossos dias, teria ocorrido um "crescimento histórico" análogo ao crescimento orgânico da humanidade. Faltaria, porém, a essas prerrogativas, uma maior problematização histórica. Em suas palavras, faltaria saber como, por exemplo, o "clássico perfeito" (vollendete Klassik) ou a "soberania da arte" (Herrschaft der Kunst) se relacionavam com os poderes de sua época, mantenedores da escravidão. Neste sentido, Benjamin conclui, dizendo que qualquer estudo sobre o "clássico" deve levar em conta as relações histórico-sociais; caso contrário, não estará completo.

Não há propriamente uma contradição entre os dois textos citados, apenas uma diferença de ênfase que não deve ser considerada só pelo aspecto de reflexões "metafísicas-juvenis" ou "materialistas-maduras". Essa ambivalência, como se pode notar pela análise de textos diferentes ou no interior de um único texto, parece ser independente de época em que foram escritos. As posições contrárias, que tomamos por ambíguas, determinam no interior do texto um "jogo" de forças entre conceitos opostos, extremos. Alguns intérpretes costumam definir essa "estratégia" benjaminiana como uma "ótica dialética" que lidaria propositalmente com designações opostas (como a de "antigo e novo", "tradição e moderno", "experiência e pobreza"), ou uma "dialética ambivalente", ou ainda como uma "técnica de contrastes dialéticos", visando distinguir o seu procedimento do sentido tradicional de dialética. Segundo Stoessel, a dialética de Benjamin não deve ser entendida no sentido hegeliano ou marxiano, mas como uma figura do pensamento que conserva a tensão do movimento dialético, sem resultar em conciliação ou superação. A analogia, segundo Stoessel, não existe em função do estabelecimento de causalidades, mas de "afinidades" e "correspondências" - dois conceitos que Benjamin desenvolve em ensaios literários, do romance de Goethe As afinidades eletivas e da ideia de "correspondance" em Baudelaire. ${ }^{5}$

Outra acusação de deslocamento histórico, capaz de conduzir menos ao idealismo e à projeção de uma recuperação do estado de totalidade perdido, e mais ao esteticismo - ao abismo do esteticismo -, se conforma na crítica que Benjamin dirige, no Trauespiel-Buch, a Nietzsche. Benjamin considera relevantes alguns aspectos da teoria nietzscheana da tragédia, mas não perdoa seu esteticismo, criticando-o radicalmente por isso. A "vã tentativa de apresentar [o trágico] como algo de universalmente humano", diz Benjamin, adviria da explicação dada pelo homem moderno ao perceber a configuração do destino trágico nas obras que nos foram legadas do passado. Para ele nada é mais "problemático" ao homem moderno do que este julgamento baseado apenas em impressões recebidas das obras do passado. Haveria presunção e arrogância na tentativa de se criar princípios generalizados em relação ao trágico, além da falsa ambição de acreditar ser possível escrever tragédias no mundo moderno. Os dois autores que o apoiam nessa crítica, citados algumas repetidas vezes, são Franz Rosenzweig ${ }^{6}$ e Georg Lukács, sendo este último filiado a Hegel na adoção do pressuposto histórico-filósofico aplicado à estética e à teoria da arte. O prenúncio do "abismo do esteticismo" no qual Benjamin faz a teoria de Nietzsche sobre a tragédia precipitar é assim considerado:

Cadernos Benjaminianos, Número especial, Belo Horizonte, 2013, página 55-69 
O mito trágico é para Nietzsche uma construção puramente estética, e a interação de energias apolíneas e dionisíacas, da aparência e dissolução da aparência, permanece restrita à esfera estética. Tendo renunciado a um conhecimento histórico-filosófico do mito trágico, Nietzsche pagou um preço alto por seu projeto de emancipar a tragédia dos lugares-comuns morais com que os comentadores a desfiguravam. A formulação clássica dessa renúncia é a seguinte: "Uma coisa deve ficar bem clara para nós, para nossa humilhação e exaltação - a comédia artística não é de modo algum representada por nós, para nosso aperfeiçoamento ou nossa ilustração, e não somos os verdadeiros criadores daquele universo artístico. Devemos, pelo contrário, admitir que somos para seus criadores imagens e projeções artísticas, e que é na significação das obras de arte que chegamos à nossa mais alta dignidade - pois somente como fenômenos estéticos são o mundo e a existência justificados para sempre - enquanto a nossa consciência dessa significação não é mais clara que a que os guerreiros pintados numa tela têm da batalha nela representada". 7 Abre-se o abismo do esteticismo, no qual esse intuitivo genial acabou perdendo todos os conceitos, e assim os deuses e os heróis, o desafio e o sofrimento, os pilares da construção clássica, evaporam-se num puro nada. Quando a arte ocupa na existência uma posição tão central que os homens são vistos como manifestações dessa arte, e não como o seu fundamento, não como seus criadores, mas como os temas eternos das criações artísticas, podemos dizer que não há mais base para a reflexão racional. ${ }^{8}$

Com base nessa severa crítica, Benjamin constrói a distinção entre o significado de tragédia e o Trauerspiel - termo, como já observado, de difícil tradução normalmente traduzido por tragédia (a língua alemã dispõe também da palavra Tragödie e é desta que Benjamin quer separar o sentido de Trauerspiel). A crítica a Nietzsche, na qual ele inclui Schopenhauer, serve a Benjamin como sustentação à distinção entre tragédia e drama barroco. É com base nesse impulso, portanto, que ele passa a discriminar o que qualifica ser o Trauerspiel: uma ideia sustentada na associação com o luto (Trauer) e com o jogo (Spiel), um jogo fúnebre ou um luto lúdico. O luto é importante na distinção com a tragédia, pois este não condiz com os sentimentos por ela despertados, quais sejam, segundo a Poética de Aristóteles, os de horror e piedade. A equivalência entre os gêneros ignoraria, portanto, um elemento do Trauerspiel de primeira relevância na interpretação de Benjamin. Identificada esta primeira diferença, ressalve-se ainda que se o drama barroco não desperta o sentimento de horror e piedade, e que, por outro lado, também não visa a despertar a emoção do luto no espectador, mas sim a mostrar a cena deste, composta de descrições de luto. Descrições ostensivas do luto. A ostentação seria uma herança do teatro renascentista italiano, composta por procissões e adornos móveis, característica que teria determinado a mobilidade como estilo ao mostrar um deslocamento de cena constante neste tipo de teatro, um teatro "peregrino", no qual não há um lugar fixo, um "tópos cósmico" como aquele que amparava a cena trágica na antiguidade grega. A palavra "Trauer", como prefixo reunido a outras palavras, parece criar uma linguagem que oscila entre o luto e a ostentação. É o que diz Benjamin, ao citá-las: Trauerbühne (palco fúnebre), Trauergepränge (pompa/suntuosidade/fausto-fúnebre).

Cadernos Benjaminianos, Número especial, Belo Horizonte, 2013, página 55-69 
A crítica dirigida ao classicismo engloba as teorias revitalizadoras da tragédia na época moderna, mas há claramente distinções entre essas. Nietzsche não pode ser facilmente reunido a Schiller, Hegel e Lukács. Estes se encontram mais sedimentados na discussão sobre o classicismo que repercute na figura do símbolo como ideal de totalidade, ao passo que Nietzsche repercute a crítica ao esteticismo, ao que pode ser associado, por extensão, com o decorativo.

\section{A expressão religiosa do sentimento de nostalgia na filosofia do classicismo e em Benjamin: messianismo cristão e messianismo judaico}

Podemos dizer que em geral há uma concordância entre Schiller, Hegel, Lukács e Benjamin com relação à transição histórica, situada na oposição entre antigo e moderno. Schiller, Hegel e Lukács conduzem essa questão situando o sentimento de nostalgia do passado harmonioso, ao mesmo tempo em que saúdam os "frutos" do rompimento com ele, depositando na reflexão e na liberdade o encaminhamento de uma reconciliação com o sentido de totalidade perdida, o que é expresso de maneira diferenciada por cada um. Suas teorias conferem à arte tal autonomia, na qual a criação ou produção diz respeito só ao talento do gênio criador. Como Benjamin incorpora essa questão e qual seria sua concepção de paraíso? - tendo em vista que, para os três filósofos mencionados, esta é uma noção que possui equivalência no ideal clássico da comunidade harmônica da Grécia antiga, havendo em Lukács uma adequação desse paradigma ao estatuto da comunidade pré-capitalista. Pode-se afirmar uma vigência dessa noção com a mesma equivalência dos esquemas anteriores que repetem, de modo diferente, o esquema religioso das instâncias do paraíso, do "pecado original" e da redenção?

Trata-se de um assunto polêmico em Benjamin, abordado de maneira diferente por alguns intérpretes. O modelo bíblico, por assim dizer, aparece com ênfase em seu ensaio de juventude - "Sobre a língua em geral e sobre a língua dos homens", de 1916, e volta a aparecer no Trauerspielbuch.

O primeiro texto configura a ideia de "língua adâmica" ou "língua paradisíaca", cuja correspondência se encontra no ato de Adão nomear as coisas, por meio do qual se reconhecia a instância criadora do verbo divino. "A criação, diz Benjamin, aconteceu através do verbo e a essência linguística de Deus é o verbo. Toda a língua humana é só um reflexo do verbo no nome". ${ }^{9}$ Havia, nesse sentido, uma imediaticidade no conhecimento das coisas mediante a nomeação adâmica, pois nela se reconhecia, em essência e em ato, a criação divina que ocorreu através do verbo. Esse conhecimento imediato, rompido com o "pecado original", foi substituído por uma profusão de línguas - cuja imagem se traduz na Torre de Babel -, tornando-se, em consequência dela, um conhecimento mediatizado. A ligação com a língua paradisíaca, porém, não se extinguiu, do que se pode deduzir que toda língua busca sempre uma reaproximação do estado linguístico original, ou seja, o da nomeação adâmica. As línguas, portanto, não seriam somente um "meio" de comunicação neutro e exteriorizado, mas possuiriam, em essência, a dimensão nomeadora. Nome e palavra são duas designações que passam a distinguir, nesse sentido, dois estados diferentes: o estado paradisíaco da língua adâmica e o estado marcado pelo "pecado original”, do qual surge a palavra humana. Segundo Haroldo de Campos,

a palavra exteriormente comunicante era nada mais nada menos do que a marca do 'pecado original do espirito linguistico', a 'paródia' do verbo criador divino: o sinal da queda, ou da ruína (Verfall), do 'beato espiríto 
linguístico, o adamítico'. Ao lado de sua função comunicativa [...], a palavra, ainda quando decaída, ostenta, como seu aspecto simbólico não redutível à mera comunicação, esta sua vocação para a língua paradisíaca, em estado de nomeação adamítica. ${ }^{10}$ (CAMPOS, 1984, p.6)

A palavra conteria, portanto, em sua essência, um caráter simbólico, no qual o conhecimento ou a Ideia surgiria em sua imediatidade. Com base nesse entendimento compõe-se a teoria da tradução benjaminiana. O exemplo bíblico e a filosofia da linguagem retornam no Trauerspielbuch, associados mais estritamente à ideia de salvação (Rettung). A concepção de "paraíso" pode, nessa obra, ser melhor entendida em comparação com o conceito de origem (Ursprung).

\section{Ursprung, Urphänomen, Enteléquia, Mônada e o curso interrompido da história}

A origem é o outro conceito de fundamental importância para a compreensão do pensamento de Benjamin, ${ }^{11}$ sendo que seu significado se distingue do conceito de gênese (Entstehung); ao contrário, estabelece-se uma oposição entre os dois sentidos. Esta última baseia-se na distinção entre "história natural" e "história no sentido globalizante de desenvolvimento temporal”. Segundo Gagnebin, Benjamin aplica "o sentido clássico de historia naturalis em oposição ao sentido moderno de desenvolvimento temporal do cosmos ou, em Marx, do desenvolvimento da espécie humana em direção à sua verdadeira humanidade".

O tempo, como sucessão temporal que Benjaminchama de "tempo homogêneo e vazio" nas "Teses" ("Sobre o conceito de História"), corresponderia a uma ordem da qual emerge a origem (Ursprung) como um salto (Sprung) para fora do fluxo contínuo temporal. Na primeira versão do prefácio de Origem do Drama Barroco Alemão, Benjamin associa a origem à noção de "enteléquia". O conceito de enteléquia, utilizado por Leibniz ao explicitar a ideia de mônada, ressalta, segundo Gagnebin,

a oposição entre uma concepção mecânica e uma concepção orgânica, ou ainda, entre um modelo físico e um modelo biológico da causalidade histórica; que ressalta igualmente a ideia de que a própria totalidade é alcançada no objeto e não só numa ordem universal, exterior aos objetos particulares. Os conceitos de origem, enteléquia e mônada estariam relacionados, portanto, a uma mesma ideia de "totalização a partir do próprio objeto". ${ }^{12}$

Outro conceito correlato ao de origem é o de proto-fenômeno (Urphänomen), que Goethe desenvolve em seus estudos sobre as ciências naturais. Benjamin diz transportar esse conceito para o domínio da história. Essa "transposição" ocorre unida à corrente da teologia judaica baseada na história do exílio e da salvação.

\section{Do naturalizante ao soteriológico: Tikkun}

O significado de origem surge, portanto, de acordo com a interpretação de Gagnebin, da confluência desses dois modelos: o da história natural e o da teologia judaica. Dessa união estabelece-se, em definitivo, uma contraposição ao modelo da

Cadernos Benjaminianos, Número especial, Belo Horizonte, 2013, página 55-69 
causalidade histórica e à ideia de gênese como início de um processo histórico. Pois, se, por um lado, a origem designa uma "ideia de totalidade a partir do objeto", cuja determinação é de ordem "naturalizante", por outro ela é o indício de uma totalidade ainda não realizada, ao apontar para a salvação. Neste tocante, fez-se importante lembrar a salvação no contexto da teologia judaica - advento que depende da vinda do salvador, o Messias - ainda não ocorreu. Transita-se, dessa maneira, de uma ordem "naturalizante" para outra de cunho "soteriológico".

O movimento da origem é compreendido, nesse sentido, como "restauração" eem paralelo, como "inacabamento". No primeiro caso, há uma lembrança da ordem harmônica que foi esquecida ou destruída, no segundo, uma advertência de que a restauração dessa ordem primordial está incompleta e pode, inclusive, estar perdida para sempre ou mesmo correr o risco de ser falseada. Como consequência, a salvação deve ser sempre entendida sob o prisma da lembrança que se tem da ordem harmônica primordial, mas que, contudo, não é em si uma garantia de que o objeto da lembrança vá ser novamente "reconciliado" como uma ordem global e harmônica. A ênfase soteriológica unida ao conceito de origem afasta o pensamento de Benjamin dos pressupostos que conferem à história um télos determinado, apoiado numa compreensão de progresso.

Há, contudo, outra influência da mística judaica, resultante de sua amizade com Scholem, que demonstra um maior rompimento com a ideia de paraíso. Trata-se da doutrina herética de Isaac Luria, relacionada à teoria da história e ao conceito de "salvação". Esta influência ajuda a elucidar a ideia de criação na mística judaica, que contém já de início a noção de exílio - sendo essa mais radicalizada na mística luriana -, em oposição à ideia de paraíso.

A teoria luriana fundamenta-se na concepção do Zimzum que, segundo Scholem, originalmente "significa 'concentração' ou 'retração', mas se usado em linguagem cabalística é melhor traduzido por 'retração' ou 'retirada'”. O Zimzum parte de uma ideia talmúdica, segundo a qual Deus havia concentrado e contraído todo seu poder em um único ponto, ao mesmo tempo em que havia se separado de sua Chechina ou "presença divina", interpretada pela cabala como o elemento ou parte feminina de Deus. Luria e sua escola interpretam essa ideia não como "a concentração de Deus em um ponto, mas como sua retirada de um ponto". ${ }^{13}$ A criação divina, nesse momento inicial, torna-se, portanto, um autoexílio de Deus em sua própria totalidade. No movimento de retração, Deus abre um espaço para a criação do mundo. A criação, por conseguinte, não ocorre por emanação divina, mas surge do nada, ou seja, do espaço criado por sua retirada. Num segundo momento, há um sinal de emanação divina através de raios de luz. As luzes são capturadas em recipientes ou "vasos" criados para abrigá-las. Os seres estão dispostos à emanação de luz, de cujo impacto ocorre a "quebra dos vasos' ou Schebira. A Schebira corresponde, portanto, a um "defeito original", do qual resulta um estado de fragmentação. Restituir as partes ao todo inicial e libertar Deus de seu exílio unindoo a sua Chechina - sua parte feminina em exílio -, significa a "salvação" ou, em termos cabalísticos, o Tikkun.

Tikkun quer dizer restituição ou reintegração à unidade original. Essa doutrina possui uma estreita relação com a teoria da história benjaminiana, segundo a qual a "salvação não consiste em uma recriação inteiramente nova, mas em um longo e paciente recolhimento desses pedaços perdidos e dispersos". ${ }^{14} \mathrm{O}$ trabalho de recolhimento dos "cacos" é atribuído, em Sobre o conceito de história, ao historiador materialista, função também conferida a outros tipos criados por

Cadernos Benjaminianos, Número especial, Belo Horizonte, 2013, página 55-69 
Benjamin, sendo, entre eles, o colecionador o de maior importância, mas também o trapeiro ou catador de restos. Porém, em cada fragmento recolhido, encontra-se um sentido a ser interpretado, e compete só ao historiador materialista decifrar no objeto particular o significado do todo. Neste sentido, as partes singulares teriam a capacidade de expressar o todo, visão que se opõe a uma 'construção' da totalidade como sistema.

Totalidade, sistema e tratado: o prefácio do Trauerspielbuch

A oposição entre "sistema” e "tratado", formulada por Benjamin nas "Questões introdutórias de crítica do conhecimento" do Trauerspielbuch, remete a uma ordem metodológica utilizada na própria composição dessa obra. O sistema visaria à total apropriação de seu objeto, ao passo que o tratado seria comparado à técnica artística do mosaico, no sentido em que "ele justapõe fragmentos de pensamento do mesmo modo que o mosaico justapõe fragmentos de imagens". Benjamin retoma a ideia de interrelacionamento entre micro e macrocosmo a partir da relação entre a forma do tratado medieval e a figura do mosaico, ao mesmo tempo em que aborda a questão da "imediatidade", quando diz

O valor desses fragmentos de pensamento é tanto maior quanto menor sua relação imediata com a concepção básica que lhes corresponde, e o brilho da apresentação depende desse valor da mesma forma que o brilho do mosaico depende da qualidade do esmalte. A relação entre o trabalho microscópico e a grandeza do todo plástico e intelectual demonstra que o conteúdo de verdade só pode ser captado pela mais exata das imersões nos pormenores do conteúdo do objeto. ${ }^{15}$

O tratado, bem como o comentário no contexto da análise literária, relaciona-se de forma negativa com a apreensão cognitiva "imediata”, remetendo a procura da verdade não a "uma coincidência falsamente imediata entre um passado sempre 'atual' e um presente narcísico, mas (à que) exige um decifrar paciente das distâncias históricas". ${ }^{16}$

\section{Alegoria e símbolo}

A concepção da totalidade na estética clássica supõe uma imediatez, cuja apreensão ocorre por meio da representação simbólica. Para melhor caracterizar essa representação, o pensamento classicista opõe-lhe a representação alegórica. O símbolo representa uma união de aspectos díspares num conjunto harmonioso e pleno de sentidoe sua apreensão ocorre de maneira clara e imediata. A alegoria, ao contrário, não designa a compreensão imediata e plena de sentido, ela transporta o significado para a instância intelectual que deve interpretar o seu sentido, correspondendo a um ato de releitura e interpretação, cujo "modelo" provém da leitura dos textos sagrados, nos quais o significado deve ser sempre reinterpretado dada a ausência de seu contexto original. A visão alegórica, por sua vez, adapta-se ao cenário de fragmentos e ruínas - ao qual Benjamin adequa a categoria do barroco - ao passo que o símbolo sempre supõe a totalidade harmoniosa.

Cadernos Benjaminianos, Número especial, Belo Horizonte, 2013, página 55-69 
Há pelo menos três sentidos da utilização da alegoria em Benjamin. O primeiro relaciona-se à influência provinda da mística judaica junto à tradição exegética de leitura dos textos sagrados. O segundo representa um forte elemento de crítica à estética clássica e à romântica, situado na teoria sobre o drama barroco. E, por último, ela se aplica à esfera da modernidade, reflexão que Benjamin desenvolve em seus ensaios sobre Baudelaire. Interessa-nos abordar o segundo sentido.

Benjamin dedica a última parte de sua tese à alegoria junto ao drama barroco (Allegorie und Trauerspiel). Inicia elaborando uma crítica ao conceito de símbolo no romantismo, cujo significado já havia sido postulado pelo classicismo.

O namoro dos teóricos da estética romântica com um conhecimento absoluto que fosse brilhante e, em última instância, descompromissado, fez com que, nos mais simples debates sobre teoria da arte, se instalasse um conceito de símbolo que não tem nada em comum com o autêntico, a não ser o nome. ${ }^{17}$

O verdadeiro conceito de símbolo estaria relacionado, segundo diz, à esfera teológica. Se essa formulação "profana" do conceito de símbolo tem como pressuposto a integração entre conteúdo e forma, Benjamin diz que é por faltar-lhe um "rigor dialético", mostrando que a pretensa integração estaria desfeita, pois que haveria uma desconexão "do conteúdo na análise da forma e a forma, na estética do conteúdo". Tanto o classicismo quanto o romantismo teriam deformado a unidade do "objeto físico e metafísico" que caracterizava o símbolo teológico, transportando-o para uma mera relação de aparência e essência.

Benjamin se reporta ao momento em que se estabeleceu a oposição entre símbolo e alegoria. A alegoria, a partir de então, foi utilizada como um conceito "especulativo", que serviria de "fundo escuro" ao "luminoso" mundo do símbolo. Importa a Benjamin dizer que o "pensamento simbolizante" não se preocupou com uma investigação da expressão alegórica em seu sentido original. Teria havido, ao contrário, uma "reconstrução negativa" da expressão alegórica, que, aliás, nem chega a ser entendida como forma de expressão, mas como um "mero modo de designação". Esse "preconceito classicista", elaborado primeiramente por Goethe, manteve-se, até mais tarde, por exemplo, em Schopenhauer, em cujo pensamento permanece a definição que associa a alegoria ao conceito e o símbolo à ideia.

A partir dessa introdução crítica, Benjamin se propõe a ver a alegoria como "forma de expressão" tão representativa quanto a fala e a escrita e não simplesmente como uma "brincadeira técnica com imagens" 18 , assim como a escrita também não pode ser remetida apenas a um mero "sistema convencional de signos". ${ }^{19}$ Junto à alegoria, Benjamin estaria relevando o próprio Barroco, como um estilo, em função da "técnica alegórica" ser seu principal "instrumento" de representação.

Assim, com relação ao símbolo, Benjamin ressalta a teoria de Creuzer que, ao destacar como o caráter de imediatidade do símbolo teria contribuído para esclarecer, indiretamente, o "conhecimento alegórico". A distinção entre símbolo e alegoria determinar-se-ia a partir de quatro elementos: "o momentâneo, o total, o insondável de sua origem, o necessário". Apesar de Creuzer manter o "preconceito classicista" com relação à exaltação do símbolo, ele teria investigado a alegoria associando-a ao contexto da mitologia. De sua teoria surgiu um comentário, de Görres, que trouxe outro esclarecimento à oposição fundada entre os dois termos. $\mathrm{O}$ símbolo estaria relacionado ao mundo natural fechado em si mesmo junto ao

Cadernos Benjaminianos, Número especial, Belo Horizonte, 2013, página 55-69 
elemento temporal de imediatidade (momentânea), e a alegoria à história humana em progressão. Nesse caso, a "medida temporal da experiência simbólica", segundo Benjamin, corresponde ao "momento da epifania, onde o símbolo incorpora o sentido ao seu interior oculto e, por assim dizer, florestal". A interpretação de Creuzer e a de Görres é, dessa maneira, determinante ao marcar a importância de "medida temporal" em ambas as expressões. A partir disso, Benjamin pôde, após criticar o uso "arbitrário" do conceito de símbolo pelo classicismo e romantismo, desfazer a oposição como tal, reabilitando a expressividade da alegoria, e em paralelo manteve a expressividade "epifânica" do símbolo. Essa expressividade aparece no uso de algumas metáforas em seus textos e ensaios, caracterizado, por exemplo, na instantaneidade do "relâmpago". Isso significa dizer, em outras palavras, que, mantendo os dois sentidos de símbolo e alegoria separados e concomitantemente expressivos, Benjamin não está optando por um sentido e denegrindo o outro. Podemos perceber essa "intenção" por meio de uma passagem bastante conhecida dessa parte de sua tese:

Enquanto que, no símbolo, com a idealização do ocaso, a face resplandente da natureza se revela de modo fugaz à luz da redenção (Erlösung), na alegoria, jaz aos olhos de quem a contempla a facies hippocratia da história como uma paisagem arcaica petrificada. A história, com tudo o que desde o início tem de extemporâneo, sofrido, malogrado, se exprime num rosto - não numa caveira. ${ }^{20}$

Pode-se supor que Benjamin lida aqui com as oposições, que a princípio designamos como natureza e história da salvação. O barroco, porém, se inscreveria no bojo da história da salvação em sentido profano, como "queda". A história, na exposição barroca, é

história do sofrimento do mundo, ela só é significativa nas etapas da sua queda. Há tanto de significação quanto de caída para a morte, pois é a morte que mais profundamente traça como um sulco a linha de demarcação dentada entre phýsis e a significação. Mas se a natureza desde sempre está caindo para a morte, então ela é também, e desde sempre, alegórica. Significação e morte amadurecem no desdobramento histórico da mesma maneira como eles se entrelaçam estreitamente como germes no estado de pecado, privado de graça, da criatura. ${ }^{21}$

\section{Alegoria e o barroco}

A visão histórica do Barroco se insere num momento peculiar, sendo, de um lado, herdeira do cristianismo medieval, do qual privilegia as categorias do pecado e da queda, e, de outro, parte para um crescente sentido de secularização em detrimento da história da salvação. Na Idade Média, contudo, a alegoria era uma mediação concernente à revelação de um sentido metafísico através de imagens ou signos. A alegoria barroca continua a ser uma forma de conhecimento mediatizado, pois a revelação deixou de existir. Não há mais um significado a ser revelado e a alegoria torna-se, nesse caso, uma mediatização potencializada, posto que qualquer significação remete a outra, infinitamente. Benjamin compara o Barroco a um jogo

Cadernos Benjaminianos, Número especial, Belo Horizonte, 2013, página 55-69 
fúnebre (Trauerspiel), no qual o sentimento de melancolia suplanta qualquer busca real por um sentimento imanente. A interpretação alegórica no Barroco é "tomada de vertigem", como diz Gagnebin, porque "não há mais um ponto fixo, nem no objeto nem no sujeito, que garanta a verdade do conhecimento".

Benjamin, dessa maneira, não está negando o caráter de arbitrariedade da alegoria - que se estabelece entre a imagem e o sentido -, nem ao menos a sobrepõe à noção de símbolo. O que Benjamin muda, ao caracterizar a visão alegórica do Barroco como sinal de deficiência a partir da decomposição da natureza, incorrendo na cena do fragmentário, da ruína e da morte -, é estabelecer como a própria tipologia da representação alegórica era considerada inferior. Prevalecia a visão clássica da natureza espelhada nas noções de harmonia, símbolo, totalidade e finitude; ou a do romantismo por meio do sentimento de nostalgia, contrabalanceado ao de reflexão e liberdade junto à aspiração infinita por uma totalidade redimida. Há, portanto, uma reabilitação da alegoria em seu sentido histórico e arbitrário, bem como o barroco, que também é reabilitado como estilo artístico representativo.

\section{Considerações finais}

Poderíamos, nesse ponto, retomar o quadro esquemático do qual partimos como termo de comparação. A primeira característica notada que reúne alguns dos pensadores comentados anteriormente em relação ao classicismo revela uma mesma concepção de "idade de ouro" associada ao período clássico grego. Benjamin difere desse interesse ao privilegiar o período medieval - influência provinda do romantismo. O segundo item relaciona-se ao sentimento de nostalgia a partir da perda do estado paradisíaco. Há, sem dúvida, uma forte presença dessa proposição em Benjamin, notadamente no ensaio "O Narrador". Nesse ensaio, a ideia de uma "idade de ouro" da narração oral, da memória e da tradição se mantém, embora baseada num outro modelo histórico. A maior diferença relaciona-se à última questão, ou seja, à função dialética que conduz a uma reformulação estética, fornecendo-lhe esperanças de ver redimida a totalidade perdida. Como pudemos até agora expor, o pensamento de Benjamin, nesse caso, separa-se da tradição "clássica e dialética", posto que, se por um lado há uma concepção de "paraíso", esta leva em conta a "distância" histórica que determina a degenerescência de seu significado imanente; sendo que, por outro, não há garantia alguma de uma reconciliação com o sentimento de totalidade. Ou seja, a "dialética", no sentido empregado por Benjamin, não realizaria um movimento progressivo em direção a um ideal de plenitude. Esse terceiro item marca, portanto, a maior diferença de Benjamin relativamente à tradição do pensamento classicista. Mantêm-se, contudo, os traços do primeiro e segundo item, que se pode notar em sua teoria narrativa.

Ao procurar reabilitar o estilo barroco, Benjamin consegue, por um lado, transpor a conclusão a que chega a Estética de Hegel, ao incorporar mais radicalmente o elemento de negatividade já presente na designação hegeliana de arte romântica; e, por outro lado, consegue também acentuar (o que fará com mais determinação a partir de então) o caráter de dessacralização no âmbito do pensamento estético, como exemplo no ensaio sobre a reprodutibilidade técnica da obra de arte, na qual conduz o tema da "desauratização" da arte, levando em conta uma cronologia histórica caracterizada através dos períodos mágico, religioso e profano.

Cadernos Benjaminianos, Número especial, Belo Horizonte, 2013, página 55-69 
O Trauerspiel - traduzido em seu sentido literal como "jogo fúnebre" ou, segundo Haroldo de Campos, "lutilúdio" - constituiria um verdadeiro "trabalho de luto" num mundo - seja o do barroco ou da modernidade - onde não há mais um sentido a ser recomposto em sua totalidade. A visão alegórica, nesse caso, teria um comportamento mais "realista" do que a simbólica, cujo intuito de recompor o sentido de totalidade estaria inserido nesse "trabalho de luto", como diz Gagnebin, quando se relaciona aos temas "da nostalgia da origem, da perda e do esquecimento, da 'iluminação profana', da reprodução infinita de imagens que não são mais cópias de nenhum modelo". Cada conceito, expresso nessa citação, participa do contexto de um dos ensaios, artigos ou resenhas, que foram agrupados posteriormente em teorias, como, por exemplo, a da história, a da linguagem, a da tradução e a da alegoria, entre as já citadas que não são apresentadas como corpus teórico em sua integralidade. A teoria da narração benjaminiana compõe-se da mesma maneira, ou seja, a partir da junção de artigos, resenhas esparsas e, principalmente, do ensaio "O narrador”. O ensaio, escrito em 1936, contém ideias e passagens literalmente reproduzidas de artigos e resenhas que lhe antecedem.

Há uma anotação avulsa de Benjamin em que aborda o cerne do problema, a partir da questão: "Por que hoje ninguém mais pode contar histórias?" - cuja resposta dispõe-se nas seguintes teses: 1. "porque não há mais espiritualidade (Witz)"; 2. "porque as pessoas não assistem mais à morte das outras"; 3. "porque a sabedoria da tradição está sendo perdida", ou ainda: 4. "porque não há mais nenhuma vela, nenhuma luz sobre a mesa, em cujo círculo de luz o narrador construía suas imagens". Mas essas teses são desenvolvidas no ensaio "O narrador".

\begin{abstract}
This article concerns an approach to the theme of the decline of experience and the narration crisis. It is very close to the study of this subject developed over years of dedicated advisory work with Jeanne Marie Gagnebin, which resulted in a master's thesis and a doctoral dissertation. The highlight of the discussion in the academic-political context of the opposition between symbol and allegory brought forth a critical reference to the German classicism present in Trauerspielbuch and other texts usually associated with this. The theme of Jewish mysticism, religious symbol value and the concept of origin form the backdrop of the discussion.
\end{abstract}

Keywords: symbol; allegory; classicism.

\title{
Referências
}

BENJAMIN, Walter. Briefe. Vol.I-VI. Frankfurt am Main: Suhrkamp, 1998.

BENJAMIN, Walter. Documentos de cultura, documentos de barbárie: escritios escolhidos. Org. Willi Bolle. Trad. Celeste H. M. Ribeiro de Sousa et al. São Paulo: Cultrix, Ed. da Universidade de São Paulo, 1986.

BENJAMIN, Walter. Gesammelte Schriften. Vol. I-VII. Frankfurt/M.: Suhrkamp, 1991.

Cadernos Benjaminianos, Número especial, Belo Horizonte, 2013, página 55-69 
BENJAMIN, Walter. O narrador. $2^{\mathrm{a}}$ ed., trad. Modesto Carone. São Paulo, Editora Abril, 1980. (Coleção "Os pensadores")

BENJAMIN, Walter. Origem do drama barroco alemão. Org. e trad. Sérgio Paulo Rouanet. São Paulo: Brasiliense, 1984.

BENJAMIN, Walter. Origem do drama trágico alemão. $2^{\mathrm{a}}$ ed. Org. e trad. João Barrento. Belo Horizonte: Autêntica, 2013.

BENJAMIN, Walter. Passagens. Org. Willi Bolle, trad. Irene Aron e Cleonice P. B. Mourão. Belo Horizonte: Editora UFMG, São Paulo: Imprensa Oficial, 2006.

BENJAMIN, Walter. Sobre o conceito da história. In: BENJAMIN, Walter. Magia e técnica, arte e política: ensaios sobre literatura e história da cultura. 7. ed., trad. Sérgio Paulo Rouanet, São Paulo: Brasiliense, 1994, p. 222-232. - (Obras escolhidas; v. 1)

BOLLE, Willi (Org.). Apresentação à coletânea de textos: Walter Benjamin. Documentos de cultura. Documentos de barbárie (Escritos escolhidos), São Paulo: Cultrix, 1986.

CAMPOS, Haroldo. Para além do princípio de saudade. In: Folha de São Paulo, 9/12/1984, p. 6. - (Suplemento "Folhetim")

GAGNEBIN, Jeanne Marie. "O preço de uma reconciliação extorquida". In: TELES, Edson; SAFATLE, Vladimir (orgs.) O que resta da ditadura: a exceção brasileira. São Paulo: Boitempo, 2010. p. 177-186.

GAGNEBIN, Jeanne Marie. "Über den Begriff der Geschichte”. In: Benjamin Handbuch. Org. Burkhardt LINDNER. Stuttgart: Metzler, 2006. p. 284-300.

GAGNEBIN, Jeanne Marie. Alegoria, que outro dizer? mimeo. São Paulo, 1980.

GAGNEBIN, Jeanne Marie. História e narração em Walter Benjamin. São Paulo: Editora Perspectiva, 1994.

GAGNEBIN, Jeanne Marie. Lembrar, escrever, esquecer. São Paulo: Editora 34, 2006.

GAGNEBIN, Jeanne Marie. Sete aulas sobre linguagem, memória e história. Rio de Janeiro: Imago, 2005.

GAGNEBIN, Jeanne Marie. Teologia e messianismo no pensamento de Walter Benjamin. Estudos Avançados, USP, São Paulo, v. 37, 1999, p. 191-206.

GAGNEBIN, Jeanne Marie. Walter Benjamin: Os cacos da História. São Paulo: Brasiliense, 1982.

GAGNEBIN, Jeanne Marie. Zur Geschichtsphilosophie Walter Benjamins. Die Unabgeschlossenheit des Sinnes. (Tese de doutorado). Erlangen: Palm \& Enke, 1978.

HUIZINGA, Johan. El otoño de la Edad Media: estudios sobre la forma de la vida y del espíritu durante los siglos XIV y XV en Francia y en los Países Bajos. Trad. José Gaos. Madrid: Alianza Editorial, 1981.

Cadernos Benjaminianos, Número especial, Belo Horizonte, 2013, página 55-69 
LINDNER, Burkhardt. Allegorie. Benjamins Begriffe. Org. Michael Opitz, Erdmut Wizisla. Frankfurt/M.: Suhrkamp, 2000, p. 50-94.

LINDNER, Burkhardt. Benjamin Handbuch. Leben-Werk-Wirkung. Stuttgart/Weimar, Metzler, 2006.

MINOIS, Georges. História do Riso e do Escárnio. Trad. Maria Elena O. Ortiz Assumpção. São Paulo: Editora UNESP, 2003.

NEILL, Michael. Issues of Death: mortality and identity in English Renaissance Tragedy. New York: Oxford University Press, 1997.

NIETZSCHE, Friedrich. Werke. Org. Fritz Koegel. Leipzig, 1895.

SCHOLEM, Gershom. A mística judaica. Trad. Dora Ruhman. São Paulo: Perspectiva, 1972.

STOESSEL, Marleen. Dans le demi-jour: Le même et le semblable. Deux contes em images de Grandville. In: Walter Benjamin et Paris. Paris: Éd. du Cerf, 1986. p. 433-441.

TODOROV, Tzvetan. Teorias do símbolo. Lisboa: Edições 70, 1979.

WISMANN, Heinz (org.). Walter Benjamin et Paris. Colloque international 27-29 juin 1983. Paris: Éd. du Cerf, 1986.

WOHLFARTH, Irving. Haarscharf an der Grenze zu Religion und Nihilismus. Zum Begriff des Zimzum bei Gershom Scholem. In : SMITH, Gary (org.), Gershom Scholem zwischen den Disziplinen. Suhrkamp, Frankfurt/M., 1995.

WOHLFARTH, Irving. Krise der Erzählung. Krise der Erzähltheorie. Überlegungen zu Lukács, Benjamin und Jauss. In: JANETZKE-DILLNER Gisela, KLÖPFER, Rolf (org.): Erzählung und Erzählforschung im 20. Jahrhundert. Stuttgart: Kohlhammer, 1981. p. 269-288.

WOHLFARTH, Irving. Sobre algunos motivos judios en Benjamin. Trad. Esther Cohen. Revue d'Esthétique, n. 1, Toulouse, 1981.

\section{Notas}

${ }^{1}$ Ursprung des deutschen Trauerspiels, título que recebeu a tradução de Origem do drama barroco alemão segundo Sérgio Paulo Rouanet e, recentemente, a de João Barrento de Origem do drama trágico alemão. Sem entrar discussões aprofundadas sobre as traduções, optamos por nos referir ao livro do Trauerspiel, visto ser um termo não apenas de difícil adaptação para língua portuguesa, mas por ser o objeto de investigação do livro, reconceituado por Benjamin, de maneira a separá-lo da tragédia clássica e reunilo ao Lustspiel, outro termo ordinariamente traduzido por comédia, mas que pode oferecer, em sua tradução, possibilidades novas pela composição novamente com jogo e prazer.

${ }^{2}$ BENJAMIN, Documentos de cultura, documentos de barbárie, p. 9.

${ }^{3}$ Ibidem. 
${ }^{4}$ LINDNER, Allegorie, p. 53-54; trad. nossa; grifo nosso; as indicações entre parêntese se referem à edição alemça das obras de Walter Benjamin, Gesammelte Schriften.

${ }^{5}$ Este tema, parcamente aqui enunciado, é de vasto alcance e discussão entre os intérpretes, principalmente na comparação com Adorno. Vale dizer que, no encerramento do Trauerspielbuch, Benjamin refere-se ao próprio método como "talvez ainda vago e ocasionalmente ainda mesclado à história da cultura" (BENJAMIN, Origem do drama barroco alemão, p. 239), longe da afirmação do método como montagem das Passagens (BENJAMIN, Passagens, p. 502).

${ }^{6}$ Cf. E. Chaves, “'O silêncio do trágico': Walter Benjamin entre Franz Rosenzweig e Friedrich Nietzsche”. In: SELIGMANN-SILVA, Leituras de Walter Benjamin. $2^{\mathrm{a}}$ ed. São Paulo: Ed. Annablume, 2006.

${ }^{7}$ NIETZSCHE. Werke. Org. Fritz Koegel. Leipzig, 1895. p. 44-45.

${ }^{8}$ BENJAMIN, Documentos de cultura, documentos de barbárie, p. 125-126.

9 "Im Wort wurde geschaffen, und Gottes sprachliches Wesen ist das Wort. Alle menschliche Sprache ist nur Reflexe des Wortes in Namen" (BENJAMIN 1991, v. II, p. 18).

${ }^{10}$ CAMPOS, Para além do princípio de saudade, p. 6.

${ }^{11}$ Reconhece-se, no estudo deste conceito, a importância de Jeanne Marie Gagnebin, desde sua tese de doutorado ao artigo "Über den Begriff der Geschichte", no Walter Benjamin Handbuch.

${ }^{12}$ GAGNEBIN, História e narração em Walter Benjamin, p. 8.

${ }^{13}$ SCHOLEM, A mística judaica, p. 263.

${ }^{14}$ GAGNEBIN, Walter Benjamin: Os cacos da História, p. 77.

15 BENJAMIN, Origem do drama barroco alemão, p. 51; trad. modificada.

${ }^{16}$ GAGNEBIN, Walter Benjamin: Os cacos da História, p. 46.

${ }^{17}$ BENJAMIN, Documentos de cultura, documentos de barbárie, p. 18.

${ }^{18}$ BENJAMIN, Origem do drama barroco alemão, p. 18.

${ }^{19}$ Ibidem. A alegoria está próxima da escrita no sentido em que esta, para o Barroco, é uma convenção de origem sagrada. Nesse sentido, diz Benjamin: "contudo assim como a doutrina barroca concebeu a História como um acontecer fundado na criação, assim a alegoria, embora sendo uma convenção como toda escrita, só tem vigência enquanto criada, da mesma forma como a Sagrada Escritura! (apud GAGNEBIN, Alegoria, que outro dizer? p.16.

${ }^{20}$ BENJAMIN, Documentos de cultura, documentos de barbárie, p. 22; trad. modificada com base em GAGNEBIN, Alegoria, que outro dizer?

${ }^{21}$ BENJAMIN, apud GAGNEBIN, Alegoria, que outro dizer? p. 16. 